\title{
Sustained serum 25-hydroxyvitamin D concentrations for one year with cholecalciferol supplementation improves glycaemic control and slows the decline of residual $\beta$ cell function in children with type 1 diabetes
}

\author{
Utrzymywane przez rok stężenie 25-hydroksywitaminy D w surowicy poprzez suplementację \\ cholekalcyferolem poprawia kontrolę glikemii i spowalnia zanik resztkowej funkcji komórek $\beta$ \\ u dzieci z cukrzycą typu 1
}

\author{
${ }^{1}$ Ram Prakash Panjiyar, ${ }^{1}$ Devi Dayal, 'Savita Verma Attri, ${ }^{2}$ Naresh Sachdeva, ${ }^{2}$ Romesh Sharma, \\ ${ }^{1}$ Anil Kumar Bhalla
}

${ }^{1}$ Department of Paediatrics, Postgraduate Institute of Medical Education and Research, Chandigarh, India
${ }^{2}$ Department of Endocrinology, Postgraduate Institute of Medical Education and Research, Chandigarh, India

\begin{abstract}
Introduction: Studies using vitamin D for preservation of residual $\beta$-cell function (RBCF) and improvement of glycaemic control in type 1 diabetes (T1D) have shown inconsistent results. The possible causes of the discrepancies in the results are related to the dosage, type, and duration of vitamin D supplementation, C-peptide concentration at entry into the study, and the influence of glycaemic control on RBCF during supplementation.

Aim of study: To evaluate the effect of cholecalciferol supplementation on RBCF and glycaemic control in children with T1D.

Material and methods: Forty-two children aged 6-12 years and within 1-2 years of diagnosis of T1D received cholecalciferol $3000 \mathrm{IU} /$ day for one year (Group A). Thirty patients were recruited as controls (Group B). The mean changes in stimulated C-peptide levels, $\mathrm{HbA}_{1 c^{\prime}}$ fasting blood glucose (FBG), mean blood glucose (MBG), and mean total daily insulin (TDI) dose from baseline to the study endpoint were calculated.

Results: Children in Group A showed lower mean FBG, MBG, $\mathrm{HbA}_{1 \mathrm{c}^{\prime}}$ and lesser TDI as compared to Group B at all follow-up visits. However, the differences in these parameters between the two groups reached statistical significance towards the study endpoint. Within group A, the decline in C-peptide levels from baseline to the endpoint was minor $(-0.13 \pm 0.11, p$-value $=0.16)$ as compared to a substantial decline in Group B $(-0.41 \pm 0.07, p$-value $=0.00)$. Comparison of the mean decrease in stimulated C-peptide levels from baseline to the endpoint between the two groups was also statistically significant $(-0.13 \pm 0.11$ vs. $-0.41 \pm 0.07, p$-value $=0.00)$. The mean decrease in FBG and MBG in Group A were greater, whereas the comparison of the mean decrease in $\mathrm{HbA}_{1 \mathrm{c}}$ between the groups reached statistical significance at the study endpoint ( $p$-value $=0.04$ ). The decrease in the TDI was, however, similar in the two groups ( $p$-value $=0.10)$.

Conclusions: Sustained serum 25-(OH)D concentrations with cholecalciferol supplementation for one year improves metabolic control and slows the decline of RBCF in children with T1D. Larger studies with longer duration and cholecalciferol dosage stratification are suggested.

Key words:

type 1 diabetes, vitamin D supplementation, cholecalciferol, residual $\beta$-cell function, stimulated C-peptide levels, glycaemic control, children.

\section{Streszczenie}

Wprowadzenie: Badania z zastosowaniem witaminy D dla zachowania resztkowej funkcji komórek $\beta$ (residual $\beta$-cell function - RBCF) i poprawy kontroli glikemicznej w cukrzycy typu 1 (type 1 diabetes - T1D) wykazały niespójne wyniki. Możliwe przyczyny rozbieżności w wynikach są związane z dawką, rodzajem i czasem trwania suplementacji witaminą D, stężeniem peptydu C na początku badania oraz wpływem kontroli glikemii na RBCF podczas suplementacji.

Cel pracy: Ocena wpływu suplementacji cholekalcyferolem na RBCF i kontrolę glikemii u dzieci z T1D.
\end{abstract}

Dr. Devi Dayal Professor

Paediatric Endocrinology and Diabetes Unit

Department of Paediatrics

Advanced Paediatrics Centre

Postgraduate Institute of Medical 
Materiały i metody: Czterdzieści dwoje dzieci w wieku 6-12 lat po rozpoznaniu T1D na przestrzeni 1-2 lat otrzymywało cholekalcyferol w dawce 3000 j.m./dobę przez rok (grupa A). Trzydziestu pacjentów zostało zrekrutowanych jako grupa kontrolna (grupa B). Obliczono średnie zmiany stężenia peptydu C po stymulacji, $\mathrm{HbA}_{1 \mathrm{c}^{\prime}}$ stężenia glukozy na czczo (FBG), średniej wartości glikemii (MBG) i średniej całkowitej dawki insuliny (TDI) od wartości początkowej do punktu końcowego badania.

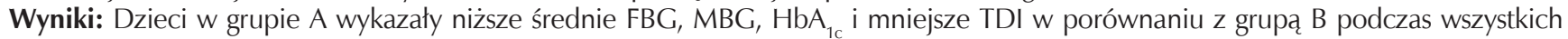
wizyt kontrolnych. Różnice w tych parametrach między dwiema grupami osiągnęły znamienność statystyczną w miarę zbliżania się do punktu końcowego badania. W grupie A zmniejszenie stężenia peptydu C od wartości początkowej do punktu końcowego było niewielkie $(-0,13 \pm 0,11, p=0,16)$ w porównaniu ze znacznym zmniejszeniem w grupie $\mathrm{B}(-0,41 \pm 0,07, p=0,00)$. Porównanie średniego zmniejszenia stężenia peptydu C po stymulacji od wartości początkowej do punktu końcowego między dwiema grupami było również statystycznie istotne $(-0,13 \pm 0,11$ względem $-0,41 \pm 0,07, p=0,00)$. Średni spadek FBG i MBG w grupie A był większy, podczas gdy porównanie średniego spadku $\mathrm{HbA}_{1 \mathrm{c}}$ między grupami osiągnęło znamienność statystyczną w punkcie końcowym badania $(p=0,04)$. Zmniejszenie TDI było jednak podobne w obu grupach $(p=0,10)$.

Wnioski: Utrzymywane stężenie 25-(OH)D w surowicy poprzez suplementację cholekalcyferolem przez rok poprawia kontrolę metaboliczną i spowalnia zanik RBCF u dzieci z cukrzycą typu 1. Zaleca się obszerniejsze badania o dłuższym czasie trwania i ze stratyfikacją dawek cholekalcyferolu.

\section{Słowa kluczowe:}

cukrzyca typu 1, suplementacja witaminą D, cholekalcyferol, resztkowa funkcja komórek $\beta$, stężenie peptydu C po stymulacji, kontrola glikemii, dzieci.

\section{Introduction}

There has been a worldwide increase in the incidence of type 1 diabetes (T1D) over the past few decades [1, 2]. Factors such as infections, intestinal microbiota, vaccines, hygiene, diet, environmental toxins, birth weight, infant growth, $\beta$-cell stress, neo-autoantigens, and vitamin D deficiency (VDD) are thought to contribute to the increasing incidence of T1D [1]. The role of VDD in the aetiopathogenesis of T1D has been extensively studied because VDD is indeed common at the onset of T1D $[3,4]$. Vitamin D supplementation may have a protective effect on the ongoing $\beta$-cell destruction and has been suggested as a potential arm of immunotherapeutic interventions after the onset of T1D $[5,6]$.

There are several advantages of preserving the residual $\beta$-cell function (RBCF) after diagnosis of T1D [7]. The endogenous insulin secretion improves long-term glycaemic control and reduces the risk of hypoglycaemia. Patients with modest RBCF levels at entry in the Diabetes Control and Complications Trial showed lesser long-term complications as compared to those with negligible RBCF. Preserved RBCF also impacts physical growth in children. However, interventions to preserve RBCF have either failed or showed only partial success [5]. Combination therapies that include vitamin $D$ have been suggested as possible future strategies to preserve RBCF in T1D [7].

The efficacy of vitamin D in preserving RBCF has been studied previously. Studies in animal models showed positive effects of vitamin D on insulin secretion and sensitivity [7]. However, clinical studies have not shown clear benefits on glycaemic control or RBCF [7]. Initial studies in patients with T1D showed no protective effect of vitamin D on RBCF $[8,9]$. However, recent studies indicate a slower decline of RBCF after supplementation [10-14]. The available data on the preservation of RBCF in T1D is still scarce and inconclusive [7]. Studies evaluating the impact of vitamin D supplementation on glycaemic control have also shown variable results. There are almost an equal number of studies showing no improvement $[8,9,14,15]$ as showing improvement [16-19] in glycaemic control. Nevertheless, the drawbacks of the previous studies related to the dosage, type and duration of vitamin D supplementation, C-peptide concentration at entry into the study, and effect of glycaemic control on RBCF during supplementation could be realised [7]. The dose of cholecalciferol supplementation selected should be able to sustain the serum vitamin $D$ concentrations required to produce immunomodulatory effects. Better preservation of RBCF was observed in studies that used higher doses $[11,13]$ as compared to those using lower doses [14]. The effect on RBCF was small with calcitriol studies $[8,9]$ as compared to studies with cholecalciferol as the type of vitamin D used $[11,13]$. The duration of cholecalciferol supplementation also appears to be an important consideration. Previous studies with longer duration of supplementation were associated with a greater protective effect on RBCF $[11,13]$ as compared to studies with shorter duration $[12,14]$. The protective effect on RBCF was shown to be lower in studies that recruited patients with negligible baseline C-peptide concentrations [8, 9] as compared to patients with higher C-peptide concentrations at inclusion [10, 11]. Additionally, a tighter control protects RBCF and may have a larger effect on preservation of RBCF during supplementation [7]. The majority of previous studies in children with T1D have been conducted without addressing all the above-mentioned factors that affect RBCF and glycaemic control. The present study was designed keeping in mind the limitations of the previous studies.

\section{Material and methods}

\section{Study design and subjects}

This prospective study included children with T1D aged 6-12 years, who attended the Paediatric Diabetes Clinic of our hospital between January 2016 and June 2017. The diagnosis of diabetes was based on the revised ISPAD (The International 
Society for Paediatric and Adolescent Diabetes) criteria [20]. The inclusion criteria were anti-glutamic acid decarboxylase 65 (GAD 65) autoantibody positivity, baseline stimulated C-peptide levels > $0.5 \mathrm{ng} / \mathrm{ml}$, and duration of diabetes between one and two years (to avoid enrolments during the honeymoon period when $\mathrm{C}$-peptide concentrations may remain variable). Patients with other chronic systemic disease or calcium disorder and those with prior intake of calcium or vitamin D or medications known to interfere with vitamin D or calcium metabolism during the past three months were excluded. The Ethics Committee of the Institute approved the study protocol. Written, informed consent from the parents or legal guardians and assent of the children was obtained before inclusion into the study.

\section{Laboratory methods}

At enrolment, blood samples for estimation of serum concentrations of glycosylated haemoglobin $\left(\mathrm{HbA}_{1 \mathrm{c}}\right)$, total 25-hydroxyvitamin D [25-(OH)D], stimulated C-peptide, calcium, phosphorus, and alkaline phosphatase were obtained. The laboratory methods used in the present study were similar to those used in our previous study [14]. Briefly, $\mathrm{HbA}_{1 \mathrm{c}}$ was measured by cation-exchange chromatography (Bio-Rad, USA). Measurement of total 25- $(\mathrm{OH}) \mathrm{D}$ was done by a competitive Electrochemiluminescence Immunoassay (ECLIA) on a fully automated analyser (E 601, Roche Diagnostics GmbH, Mannheim, Germany) using kits, calibrators, and controls from the same manufacturer. The detection limit of this method is $3.0 \mathrm{ng} / \mathrm{ml}$ with inter-assay and intraassay CV of $13.1 \%$ and $6.8 \%$, respectively. Stimulated C-peptide concentrations were estimated two hours after consumption of a standardised liquid mixed meal in the morning after an overnight fast, by sandwich ECLIA on the same automated analyser using kits and calibrators provided by the same manufacturer. The lower limit of detection of the method used is $0.01 \mathrm{ng} / \mathrm{ml}$, and intra-assay and inter-assay CV of $4.6 \%$ and $5.0 \%$, respectively. Besides internal controls, the tri-level Lyphocheck Immunoassay Plus Control kits (Bio-Rad Laboratories, Irvine, CA) were used as external controls. Urinary calcium-to-creatinine ratio was estimated at baseline and at 12-month follow-up in Group A. The laboratory personnel were blinded to the intervention.

\section{Intervention and follow-up}

The intervention group received cholecalciferol $3000 \mathrm{IU} /$ day for one year (Group A) while age-matched controls received no intervention (Group B). No change was made in the insulin regimen. Parents were instructed to maintain a record diary of self-monitored blood glucose (SMBG) done 3-4 times per day (fasting, pre-lunch, pre-dinner, and between 1 and 2 a.m.), insulin doses, and any unusual events. The frequency of SMBG was reduced due to cost constraints even though ISPAD recommends this 4-6 times or more per day [20]. All parents used either Freestyle Optium H (Abbott Laboratories, Illinois, U.S.A) or Accu-Chek ${ }^{\circledR}$ Active (Roche Diagnostics GmbH, Mannheim, Germany) glucometers. The changes in the daily insulin dosages were made on a treat-to-target basis with premeal and postprandial SMBG titration goals of $80-130 \mathrm{mg} / \mathrm{dl}$ and $\leq 180 \mathrm{mg} / \mathrm{dl}$, respectively, and adjustments to avoid hypoglycaemia. Calcula- tion of mean insulin dose, mean fasting blood glucose (FBG), and mean blood glucose (MBG) levels was done using the diary records of seven consecutive days before the clinic visit.

For both groups of patients, the follow-up visits were scheduled at three monthly intervals for the study duration of one year. At each visit, a thorough physical examination was conducted in addition to measurement of $\mathrm{HbA}_{1 \mathrm{c}}$. Monitoring for vitamin $\mathrm{D}$ toxicity was done by measuring total $25-(\mathrm{OH}) \mathrm{D}$ concentrations, serum calcium, phosphorus, alkaline phosphatase, and spot urine calcium-creatinine ratio for children in Group A. Measurement of total 25- $(\mathrm{OH}) \mathrm{D}$ and stimulated C-peptide levels was done in both groups at the study end. The protocol for intervention and follow-up was similar to our previous work except for dosage and duration of supplementation [14].

\section{Outcome Parameters}

The primary outcome measure was the change in stimulated C-peptide levels whereas the secondary outcome parameters were the changes in mean $\mathrm{HbA}_{1 \mathrm{c}}$, mean $\mathrm{FBG}, \mathrm{MBG}$, and mean total daily insulin (TDI) from baseline to study endpoint.

\section{Statistical analysis}

The data entry and statistical analysis were done on Microsoft Excel 2007 (Microsoft, Redmond, WA) and Statistical Software for Social Sciences (SPSS) (IBM SPSS Statistics for Windows, Version 20.0. Armonk, NY: IBM Corp). Descriptive statistics were calculated, such as mean, standard deviation, minimum, and maximum, for representation of the quantitative variables, whereas frequency and percentages were calculated for qualitative variables. Normality of the data was checked by Kolmogorov-Smirnov test and equality of variances by Levene's test. The comparison between the two groups was done by paired Student's t-test or repeated-measures analysis of variance (ANOVA). Analysis of covariance (ANCOVA) was also used to compare baseline values between groups, using age and sex as covariates. A p-value of $<0.05$ was considered significant.

\section{Results}

\section{Characteristics of the study population}

Group A comprised of 42 children (32 [76\%] boys) whereas Group B had 30 children (16 [53\%] boys). The mean age was similar in the two groups ( $8.48 \pm 2.28$ years vs. $8.92 \pm 2.50$ years; $p$-value $=0.44$ ). The majority of the patients (40 in Group A and 29 in Group B) were using basal-bolus insulin regimen (Glargine/Detemir and Aspart/Lispro); only three (two in Group A and one in Group B) were on the split-mix regimen (Insulin NPH and Regular). All patients were positive for anti-GAD 65 autoantibodies done routinely at our hospital [21]. At baseline, there were no gender differences in mean values of $25-(\mathrm{OH}) \mathrm{D}(27.95$ \pm 0.86 in boys vs. $24.69 \pm 9.03$ in girls, $p$-value $=0.08)$ and stimulated C-peptide (0.92 \pm 0.86 in boys vs. $0.71 \pm 0.27$ in girls, $p$-value $=0.24)$. The glycaemic control was similar between vitamin D sufficient and vitamin D deficient subjects at baseline (mean $\mathrm{HbA}_{1 \mathrm{c}}$ levels $10.3 \pm 2.5$ vs. $10.3 \pm 2.9$, $p$-value $=0.96$ ). 
Table I. Clinical, biochemical, and hormonal data of the patients in the two study groups at baseline and in follow-up

\begin{tabular}{|c|c|c|c|c|}
\hline Variable & Time points & $\begin{array}{l}\text { Group A }(n=42) \\
\text { Mean } \pm \text { SD }\end{array}$ & $\begin{array}{l}\text { Group B }(n=30) \\
\text { Mean } \pm \text { SD }\end{array}$ & $p$ \\
\hline \multirow{3}{*}{$\begin{array}{l}\text { Body mass index } \\
\left(\mathrm{kg} / \mathrm{m}^{2}\right)\end{array}$} & Baseline & $15.95 \pm 2.70$ & $15.28 \pm 2.21$ & 0.26 \\
\hline & 6 months & $16.14 \pm 2.82$ & $16.03 \pm 1.59$ & 0.84 \\
\hline & 12 months & $16.68 \pm 2.89$ & $15.66 \pm 1.64$ & 0.08 \\
\hline \multirow{3}{*}{$\begin{array}{l}\text { Daily insulin dose } \\
(\mathrm{U} / \mathrm{kg} / \mathrm{d})\end{array}$} & Baseline & $0.99 \pm 0.51$ & $1.27 \pm 0.87$ & 0.09 \\
\hline & 6 months & $0.76 \pm 0.41$ & $0.92 \pm 0.36$ & 0.09 \\
\hline & 12 months & $0.58 \pm 0.28$ & $0.93 \pm 0.44$ & 0.00 \\
\hline \multirow{3}{*}{$\mathrm{HbA}_{1 \mathrm{c}}(\%)$} & Baseline & $10.5 \pm 2.92$ & $10.0 \pm 1.98$ & 0.41 \\
\hline & 6 months & $7.26 \pm 1.48$ & $7.62 \pm 1.18$ & 0.27 \\
\hline & 12 months & $7.76 \pm 1.83$ & $8.92 \pm 2.78$ & 0.03 \\
\hline \multirow{3}{*}{$\begin{array}{l}\text { Fasting blood glucose } \\
(\mathrm{mg} / \mathrm{dl})\end{array}$} & Baseline & $138.21 \pm 59.95$ & $129.80 \pm 18.09$ & 0.45 \\
\hline & 6 months & $123.05 \pm 30.73$ & $139.96 \pm 44.71$ & 0.06 \\
\hline & 12 months & $121.71 \pm 20.47$ & $133.40 \pm 24.67$ & 0.03 \\
\hline \multirow{3}{*}{$\begin{array}{l}\text { Mean blood glucose } \\
(\mathrm{mg} / \mathrm{dl})\end{array}$} & Baseline & $178.31 \pm 44.22$ & $182.68 \pm 49.60$ & 0.69 \\
\hline & 6 months & $159.98 \pm 30.83$ & $170.96 \pm 41.73$ & 0.20 \\
\hline & 12 months & $157.80 \pm 30.80$ & $182.24 \pm 40.42$ & 0.00 \\
\hline \multirow{2}{*}{$\begin{array}{l}\text { Stimulated C-peptide } \\
(\mathrm{ng} / \mathrm{ml})\end{array}$} & Baseline & $0.98 \pm 0.90$ & $0.72 \pm 0.22$ & 0.12 \\
\hline & 12 months & $0.85 \pm 1.01$ & $0.31 \pm 0.37$ & 0.00 \\
\hline \multirow{5}{*}{$\begin{array}{l}\text { Serum 25(OH)D } \\
(\mathrm{ng} / \mathrm{ml})\end{array}$} & Baseline & $29.36 \pm 15.80$ & $24.11 \pm 9.75$ & 0.11 \\
\hline & 3 months & $34.82 \pm 14.55$ & --- & --- \\
\hline & 6 months & $32.82 \pm 17.26$ & --- & --- \\
\hline & 9 months & $37.47 \pm 17.04$ & --- & --- \\
\hline & 12 months & $37.14 \pm 11.81$ & $20.78 \pm 9.62$ & 0.00 \\
\hline
\end{tabular}

The clinical, biochemical, and hormonal characteristics at baseline and in follow-up are shown in Table I.

\section{Comparison of biochemical and other parameters after} intervention

As compared to the control group, children in the intervention group showed lower mean levels of $\mathrm{FBG}, \mathrm{MBG}$, and $\mathrm{HbA}_{10}$, and lesser TDI need at all the follow-up visits, but the differences in these parameters between the two groups reached statistical significance at the study endpoint only (Table I). The mean total 25-(OH)D concentrations were similar in the two groups at baseline but increased in Group $A$ as expected and decreased in Group B at the 12-month follow-up. In Group A, the mean total $25-(\mathrm{OH}) \mathrm{D}$ concentrations remained in the sufficiency range $(>30 \mathrm{ng} / \mathrm{ml})$ at all visits. The difference in the stimulated C-peptide levels between the two groups was statistically significant at last follow-up (Table I).

The decline in stimulated C-peptide levels from baseline to the study endpoint within Group A was minor $(-0.13 \pm 0.11$, $p$-value $=0.16)$ as compared to a substantial decline in Group B $(-0.41 \pm 0.07, p$-value $=0.00)$. Comparison of the mean decrease in stimulated C-peptide levels from baseline to the study endpoint between the two groups was statistically significant $(-0.13$ \pm 0.11 vs. $0.41 \pm 0.07, p$-value $=0.00$; Table II). The mean decrease in FBG and MBG in Group A was significantly greater than that in Group B, whereas the comparison of the mean decrease 
Table II. Comparison of mean changes from baseline to the endpoint in the studied variables between the two groups

\begin{tabular}{llll}
\hline Variable & Group A $(n=42)$ & Group B $(n=30)$ & $p$ \\
\hline Fasting blood glucose $(\mathrm{mg} / \mathrm{dl})$ & $-16.5 \pm 32.44$ & $1.6 \pm 6.58$ & 0.00 \\
\hline Mean blood glucose $(\mathrm{mg} / \mathrm{dl})$ & $-20.51 \pm 13.42$ & $-0.44 \pm 9.19$ & 0.00 \\
\hline $\mathrm{HbA}_{1 \mathrm{c}}(\%)$ & $-2.74 \pm 3.0$ & $-1.16 \pm 3.60$ & 0.04 \\
\hline Daily insulin dose $(\mathrm{U} / \mathrm{kg} / \mathrm{d})$ & $-0.40 \pm 0.14$ & $-0.34 \pm 0.17$ & 0.10 \\
\hline Stimulated C-peptide $(\mathrm{ng} / \mathrm{ml})$ & $-0.13 \pm 0.11$ & $-0.41 \pm 0.07$ & 0.00 \\
\hline Serum 25(OH)D $(\mathrm{ng} / \mathrm{ml})$ & $6.75 \pm 4.65$ & $-3.33 \pm 2.55$ & 0.00 \\
\hline Serum Calcium $(\mathrm{mg} / \mathrm{dl})$ & $0.13 \pm 0.05$ & $-0.36 \pm 0.09$ & 0.00 \\
\hline Serum Phosphorus $(\mathrm{mg} / \mathrm{dl})$ & $0.07 \pm 0.42$ & $-0.06 \pm 0.13$ & 0.10 \\
\hline
\end{tabular}

in $\mathrm{HbA}_{1 \mathrm{c}}$ reached statistical significance at the study endpoint $(p$-value $=0.04)$. The decrease in TDI requirements, however, was similar between the two groups $(p$-value $=0.10$; Table II).

\section{Monitoring for vitamin $D$ toxicity and adherence to study protocol}

At the last follow-up, 25 (60\%) patients in Group A were vitamin D sufficient (total 25-[OH]D concentrations > $30 \mathrm{ng} / \mathrm{ml}$ ) compared to only three (10\%) in Group B. Twelve (40\%) patients in Group B remained vitamin D deficient (total 25-[OH]D concentrations $<20 \mathrm{ng} / \mathrm{ml}$ ) compared to none in Group A. However, the number of patients having vitamin $D$ insufficiency (total 25- $[\mathrm{OH}] \mathrm{D}$ concentrations $21-29 \mathrm{ng} / \mathrm{ml})$ were similar $(17,40 \%$ in Group A and 15, 50\% in Group B) in the two groups. In Group A, the mean serum calcium concentrations increased from 9.18 $\pm 0.59 \mathrm{mg} / \mathrm{dl}$ (range $8.20-10.45 \mathrm{mg} / \mathrm{dl}$ ) to $9.31 \pm 0.64 \mathrm{mg} / \mathrm{dl}$ (range $8.71-10.60 \mathrm{mg} / \mathrm{dl}$ ) while the mean serum phosphorus and alkaline phosphatase concentrations were similar at baseline (4.55 $\pm 0.88 \mathrm{mg} / \mathrm{dl}$, range 2.63-6.42 $\mathrm{mg} / \mathrm{dl}$ and 290.0 \pm 116.7 , range $136-652 \mathrm{IU} / \mathrm{l}$, respectively) and at the study endpoint (4.49 $\pm 0.45 \mathrm{mg} / \mathrm{dl}$, range $3.90-5.90 \mathrm{mg} / \mathrm{dl}$ and 312.5 $\pm 59.7 \mathrm{lU} / \mathrm{l}$, respectively). The spot urine calcium-creatinine ratio increased from $0.05 \pm 0.05$ (range $0.10-0.27$ ) at baseline to $0.26 \pm 0.28$ (range $0.20-0.81$ ) at the study endpoint (mean change $0.21 \pm 0.05, p$-value $=0.00$ ). There were no adverse events reported, and all patients completed the study. The adherence to the protocol was checked by verbal inquiries and by measuring laboratory parameters such as serum calcium, 25- $(\mathrm{OH}) \mathrm{D}$ concentrations, and urinary calcium-creatinine ratio.

\section{Discussion}

Our study indicates that cholecalciferol supplementation for one year in patients with T1D improves glycaemic control and reduces the rate of decline of RBCF. The results may be at- tributed to alterations made in the study protocol after learning lessons from our own experience as well as other studies [7]. The important factors for an improved outcome include patient selection criteria, type, dosage of vitamin D, and duration of supplementation, which are discussed below.

Several studies have shown that cholecalciferol supplementation is associated with an improved glycaemic control in T1D [16-19]. Conversely, VDD is associated with poor control [22]. Improvement in vitamin D status improves endogenous insulin secretion and insulin sensitivity of target tissues, thereby contributing to an improved insulin action [17-19]. Studies that showed no improvement in glycaemic control were either small $[8,9,14]$ or the vitamin $D$ doses used were unable to achieve the optimal vitamin D concentrations [14, 15]. Indeed, only $19.6 \%$ of patients in the AWeSoMe study, which showed no association of vitamin D status with glycaemic control, had vitamin D levels in the sufficient range [23].

The slower decline of RBCF in the supplemented patients was a major finding of our study. These results are similar to other studies [10-14]. The major determinant of a beneficial effect of cholecalciferol on RBCF appears to be the optimally maintained serum $25-(\mathrm{OH}) \mathrm{D}$ concentrations in the intervention group throughout the study period. The immunomodulatory effects of cholecalciferol occur only at optimal serum concentrations maintained for a sufficiently long period to achieve RBCF protection [11, 13]. Studies using the single bolus doses of cholecalciferol, therefore, do not produce appreciable benefits on RBCF [15]. Similarly, only a small effect on RBCF has been observed in studies with a short duration of supplementation $[12,14]$. Conversely, longer duration studies have detected a larger protective effect $[11,13]$. The effective immunomodulation by vitamin $D$ involves shifting of the proinflammatory immune status to a more tolerogenic phenotype [13] and sustained effects on T-cell subtypes, which are altered in T1D (24). The effects of cholecalciferol on RBCF, which occur via an increase in the percentage and suppressive capacity of Tregs, 
tend to appear after prolonged supplementation $[11,13]$. It is, however, difficult to maintain optimal serum 25- $(\mathrm{OH}) \mathrm{D}$ concentrations without using large doses of cholecalciferol. In particular, the inherited variations in vitamin $\mathrm{D}$ genes and the ethnic differences in achieving serum 25-(OH)D concentrations need consideration while selecting the cholecalciferol dosage required in a patient population $[25,26]$. For several reasons, the ability of Indian children to achieve and maintain serum 25- $(\mathrm{OH}) \mathrm{D}$ concentrations in optimal ranges is lower, and hence the requirement of oral cholecalciferol is higher than for their Western counterparts [27]. In our previous study, a daily cholecalciferol dosage of $2000 \mathrm{IU}$ was unable to achieve vitamin D concentrations in the desired ranges [14]. Even $3000 \mathrm{IU} /$ day of cholecalciferol used in the present study could barely sustain $25-(\mathrm{OH})$ $\mathrm{D}$ concentrations in sufficient ranges. Another study also suggests that cholecalciferol doses of $4000 \mathrm{IU} /$ day are well tolerated and associated with enhancement of Tregs in T1D [28].

The preservation of RBCF is better if the patients have sufficient (preferably $>0.6 \mathrm{ng} / \mathrm{ml}$ ) C-peptide concentrations at the time of initiating supplementation [11, 29]. In previous studies, the RBCF protection was better in patients with higher C-peptide concentrations at inclusion $[10,11]$. Conversely, the preservation was negligible if baseline C-peptide concentrations were lower $[8,9]$. As compared to our previous study, the C-peptide levels at inclusion were higher in the present study $(0.98 \pm 0.90 \mathrm{ng} / \mathrm{ml}$ vs. $0.48 \pm 0.28 \mathrm{ng} / \mathrm{ml}$ ), which probably contributed to an appreciable effect of cholecalciferol supplementation on RBCF [14]. Non-exclusion of patients with VDD, who show a better protective effect of vitamin D supplementation on RBCF $[11,13]$ and better glycaemic control, a significant factor for long-term complications, in the supplemented group also contributed to the slower decline of RBCF in the current study $[7,30]$.

\section{References}

1. Rewers M, Ludvigsson J. Environmental risk factors for type 1 diabetes. Lancet 2016; 387: 2340-2348. doi: 10.1016/S0140-6736(16) 30507-4

2. Dayal D, Saini AG, Jayashree M, et al. Hospital based incidence, patterns of presentation and outcome of type 1 diabetes: 12 years' data from a tertiary care center in North India. Int J Diabetes Dev Ctries 2015; 35: 103-107. doi: 10.1007/s13410-014-0238-3

3. Borkar W, Devidayal, Verma S, et al. Low levels of vitamin D in North Indian children with newly diagnosed type 1 diabetes. Pediatr Diabetes 2010; 11: 345-350. doi: 10.1111/j.1399-5448.2009.00589.x

4. Devidayal, Singh MK, Sachdeva N, et al. Vitamin D levels during and after resolution of ketoacidosis in children with new onset type 1 diabetes. Diabet Med 2013; 30: 829-834. doi: 10.1111/dme.12200

5. Ludvigsson J. Therapies to preserve $\beta$-cell function in type 1 diabetes. Drugs 2016; 76: 169-185. doi: 10.1007/s40265-015-0511-x

6. Dayal D. Comment on: "Therapies to Preserve $\beta$-Cell Function in Type 1 Diabetes". Drugs 2016; 76: 625-626. doi: 10.1007/s40265016-0560-9
We chose cholecalciferol and not calcitriol, to allow us to use higher doses without a significant risk of hypercalcaemia. A long terminal half-life of cholecalciferol protects against toxicity due to feedback inhibition of renal 1- $\alpha$ hydroxylase. Conversely, the short half-life of calcitriol may cause fluctuations in serum concentrations and inadequate suppression of the autoimmune process. The preservation of RBCF was better in studies that used cholecalciferol $[11,13,14]$ as compared to studies with calcitriol $[8,9]$. The smaller effect size in the calcitriol studies was probably attributable to low dosages used to avoid adverse effects.

Our study has several limitations. Firstly, the number of control subjects was lower than the cases. Secondly, we did not analyse the effects of specific insulin regimen on glycaemic control although the efficacy and use of both types of basal insulin were similar in our patients [31, 32]. Thirdly, we could not quantify the sun-exposure and hence the contribution of sunlight to measured serum $25-(\mathrm{OH}) \mathrm{D}$ concentrations. Higher sun-exposure scores resulting in higher 25-(OH)D concentrations may affect the response to oral vitamin D [12]. Finally, the molecular mechanism of immunomodulation by cholecalciferol remains unexplained in our patients because we did not include the T-cell parameters as studied previously $[11,13,28]$.

\section{Conclusions}

Sustained serum 25-(OH)D concentration for one year with cholecalciferol supplementation was associated with better glycaemic control and slower decline of RBCF in children with T1D. We suggest larger studies with longer observation periods and stratification of cholecalciferol dosage.

7. Dayal D, Sachdeva N. Preservation of residual beta cell function with vitamin $\mathrm{D}$ supplementation in type 1 diabetes. Immunoendocrinology 2015; 2: e1093. doi: 10.14800/ie.1093

8. Walter M, Kaupper T, Adler K, et al. No effect of the 1alpha,25-dihydroxyvitamin D3 on beta-cell residual function and insulin requirement in adults with new-onset type 1 diabetes. Diabetes Care 2010; 33: 1443-1448. doi: 10.2337/dc09-2297

9. Bizzarri C, Pitocco D, Napoli N, et al. No protective effect of calcitriol on beta-cell function in recent-onset type 1 diabetes: the IMDIAB XIII trial. Diabetes Care 2010; 33: 1962-1963. doi: 10.2337/dc100814

10. Li X, Liao L, Yan X, et al. Protective effects of 1-alpha-hydroxyvitamin D3 on residual beta-cell function in patients with adult-onset latent autoimmune diabetes (LADA). Diabetes Metab Res Rev 2009; 25: 411-416. doi: 10.1002/dmrr.977

11. Gabbay MA, Sato MN, Finazzo C, et al. Effect of cholecalciferol as adjunctive therapy with insulin on protective immunologic profile and decline of residual $\beta$-cell function in new-onset type 1 diabetes mellitus. Arch Pediatr Adolesc Med 2012; 166: 601-607. doi: 10.1001/archpediatrics.2012.164 
12. Ataie-Jafari A, Loke SC, Rahmat AB, et al. A randomized placebocontrolled trial of alphacalcidol on the preservation of beta cell function in children with recent onset type1 diabetes. Clin Nutr 2013; 32: 911-917. doi: 10.1016/j.clnu.2013.01.012

13. Treiber G, Prietl B, Fröhlich-Reiterer E, et al. Cholecalciferol supplementation improves suppressive capacity of regulatory T-cells in young patients with new-onset type 1 diabetes mellitus - a randomized clinical trial. Clin Immunol 2015; 161: 217-224. doi: 10.1016/j.clim.2015.08.002

14. Mishra A, Dayal D, Sachdeva N, et al. Effect of 6-months' vitamin D supplementation on residual beta cell function in children with type 1 diabetes: a case control interventional study. J Pediatr Endocrinol Metab 2016; 29: 395-400. doi: 10.1515/jpem-2015-0088

15. Perchard R, Magee L, Whatmore A, et al. A pilot interventional study to evaluate the impact of cholecalciferol treatment on $\mathrm{HbA} 1 \mathrm{c}$ in type 1 diabetes (T1D). Endocr Connect 2017; 6: 225-231. doi: 10.1530/EC-17-0045

16. Savastio S, Cadario F, Genoni G, et al. Vitamin D deficiency and glycemic status in children and adolescents with type 1 diabetes mellitus. PLoS One 2016; 11: e0162554. doi: 10.1371/journal. pone.0162554

17. Giri D, Pintus D, Burnside G, et al. Treating vitamin D deficiency in children with type I diabetes could improve their glycaemic control. BMC Res Notes 2017; 10: 465. doi: 10.1186/s13104-017-2794-3

18. Hafez M, Hassan M, Musa N, et al. Vitamin D status in Egyptian children with type 1 diabetes and the role of vitamin $D$ replacement in glycemic control. J Pediatr Endocrinol Metab 2017; 30: 389-394. doi: 10.1515/jpem-2016-0292

19. Felício KM, de Souza ACCB, Neto JFA, et al. Glycemic variability and insulin needs in patients with type 1 diabetes mellitus supplemented with vitamin D: a pilot study using continuous glucose monitoring system. Curr Diabetes Rev 2018; 14: 395-403. doi: 10.2 174/1573399813666170616075013

20. Craig ME, Hattersley A, Donaghue KC. Definition, epidemiology and classification of diabetes in children and adolescents. ISPAD Clinical Practice Consensus Guidelines 2009 Compendium. Pediatric Diabetes 2009; 10 (Suppl 12): 3-12. doi: 10.1111/j.1399-5448.2009.00568.x

21. Dayal D, Samprati M, Kaur N, et al. Prevalence of beta-cell, thyroid and celiac autoimmunity in North Indian children with recent onset type 1 diabetes (T1D) J Clin Diagn Res 2015; 9: SM01-2. doi: 10.7860/JCDR/2015/11960.5711
22. Wierzbicka E, Szalecki M, Pludowski P, et al. Vitamin D status, body composition and glycemic control in Polish adolescents with type 1 diabetes. Minerva Endocrinol 2016; 41: 445-455.

23. Brody J, Pinhas-Hamiel O, Landau Z, et al. Vitamin D status in Israeli pediatric type 1 diabetes patients: the AWeSoMe Study Group experience and literature review. J Pediatr Endocrinol Metab 2016. doi:10.1515/jpem-2016-0137

24. Kaur N, Minz RW, Bhadada SK, et al. Deranged regulatory T-cells and transforming growth factor- $\beta 1$ levels in type 1 diabetes patients with associated autoimmune diseases. J Postgrad Med 2017; 63: 176-181.

25. Dayal D. It's high time to revise Indian guidelines on vitamin D supplementation in children. J Pediatr Endocrinol Metab 2016; 29: 425-426. doi: 10.1515/jpem-2015-0374

26. Penna-Martinez M, Badenhoop K. Inherited variation in vitamin D genes and type 1 diabetes predisposition. Genes (Basel) 2017; 8 . pii: E125. doi: 10.3390/genes8040125

27. Dayal D, Jain M. Indian children need higher vitamin D supplementation. Indian Pediatr 2018; 55: 78.

28. Bogdanou D, Penna-Martinez M, Filmann N, et al. T-lymphocyte and glycemic status after vitamin $\mathrm{D}$ treatment in type 1 diabetes: A randomized controlled trial with sequential crossover. Diabetes Metab Res Rev 2017; 33. doi: 10.1002/dmrr.2865

29. Otto-Buczkowska E. The clinical utility of C-peptide measurement in diabetology. Pediatr Endocrinol Diabetes Metab 2015; 20: 63-68. doi: 10.18544/PEDM-20.02.0004

30. Pisarczyk-Wiza D, Zozulińska-Ziółkiewicz D, Piłaciński S, et al. Prevalence of chronic complications in patients with over 30-year history of type 1 diabetes depending on the age of onset of diabetes. Pediatr Endocrinol Diabetes Metab 2015; 20: 143-151. doi: 10.18544/PEDM-20.04.0014

31. Saini A, Devidayal, Verma $S$, et al. Comparative efficacy of once daily insulin glargine with twice daily NPH insulin in children with type 1 diabetes. J Diabetes Metab 2011; 2: 124. doi:10.4172/21556156.1000124

32. Dayal D, Sharma S, Sachdeva N, et al. Efficacy of insulin detemir compared to insulin NPH on glycemic control in Indian children with type 1 diabetes. J Diabetology 2014; 2: 2. 